\title{
LOSS OF A SYNCRETIC THEATRICAL FORM
}

\author{
Javaid Iqbal Bhat
}

\begin{abstract}
The folk theatre called Bhand Pather is probably the oldest theatre in the subcontinent if not in the world. Though the history of its evolution has not been comprehensively documented yet one can find references to it in some of the extant manuscripts. In this paper, the author attempts a complex exploration of this endangered form as a key component of tradition and its interface with modernity not merely through direct confrontation with the products like television, but also in the ideological domain.

Bhand Pather lends itself for a study of the shifting landscape of the intercommunal relationships. It is one of the unique sites on which the nuances and complexities of Kashmiriyat can be easily worked out. It has been nourished both by Hindu Shaivism and Sufi mysticism. The presence of secular characters is an eminent feature of this form. The most significant feature of this art rich with the antique flavor is the way it presents us a non-idealized version of Kashmiriyat.
\end{abstract}

Key words: Kashmir, Bhand Pather, folk theatre, history of folk theatre

Nothing defines the limits and promises of Kashmiriyat better than the Bhand Pather. Bhand Pather is an amalgam, an agglomeration or a repository of diverse rhythms. These rhythms stemming from multiple sources, some faroff and some very close. In his most recent novel Shalimar the Clown, Rushdie towards the end of this rather painful narrative bemoaning the loss of a cherished paradise on earth, depicts a very poignant scene. A Bhand Pather performance is underway in the Srinagar auditorium. Outside the auditorium, people are frenetically shouting slogans heralding the birth of a new valley or as Rushdie would have it "dawn of an age of fury" (Rushdie 2005: 45). Inside, excepting a Sikh, no one is watching the 'jashn' of the once celebrated Bhands. Not many years before, Pachigam, the fictional village - a metaphor for Kashmiriyat played host to the best troupe of traveling players or Bhands. With the near total extinction of Pachigam under the impact of a complex set of forces, the popular art of Bhands also meets its sad end. Shalimar, the tightrope walker and son of the village sarpanch, with hair as a 'mountain stream' (Rushdie 2005: 11) ends up decapitating his childhood sweetheart, Boonyi. Soon after this he himself is also mortally wounded by another character with an arrow while he is in Los Angeles baying for the blood of ex-ambassador Max Ophuls. 
Shalimar is a Muslim. Boonyi Kaul is a Hindu girl. She is the daughter of Pandit Pyarelal Kaul and is well known for her beauty and dance. Pachigam or, to be precise, Bhand Pather had united them and their families. With its fall, everything holding together the liminal intercommunal identity also comes apart. The words Hindu and Muslim that earlier had been mere descriptive terms now became sources of division.

The folk theatre called Bhand Pather is probably the oldest theatre in the subcontinent if not in the world. Though the history of its evolution has not been comprehensively documented yet one can find references to it in some of the extant manuscripts. The word Bhand with its origin in the Sanskrit "Band" meaning comical behavior or imitation is found in most of the North-Indian languages. Even today in Punjab, the Bhands are commonly addressed as Naqqal, meaning those who are adept in imitation. There are still the remnants of Mohan Bhand in Rajasthan. The medieval Bhakti poetry of Gujarat is replete
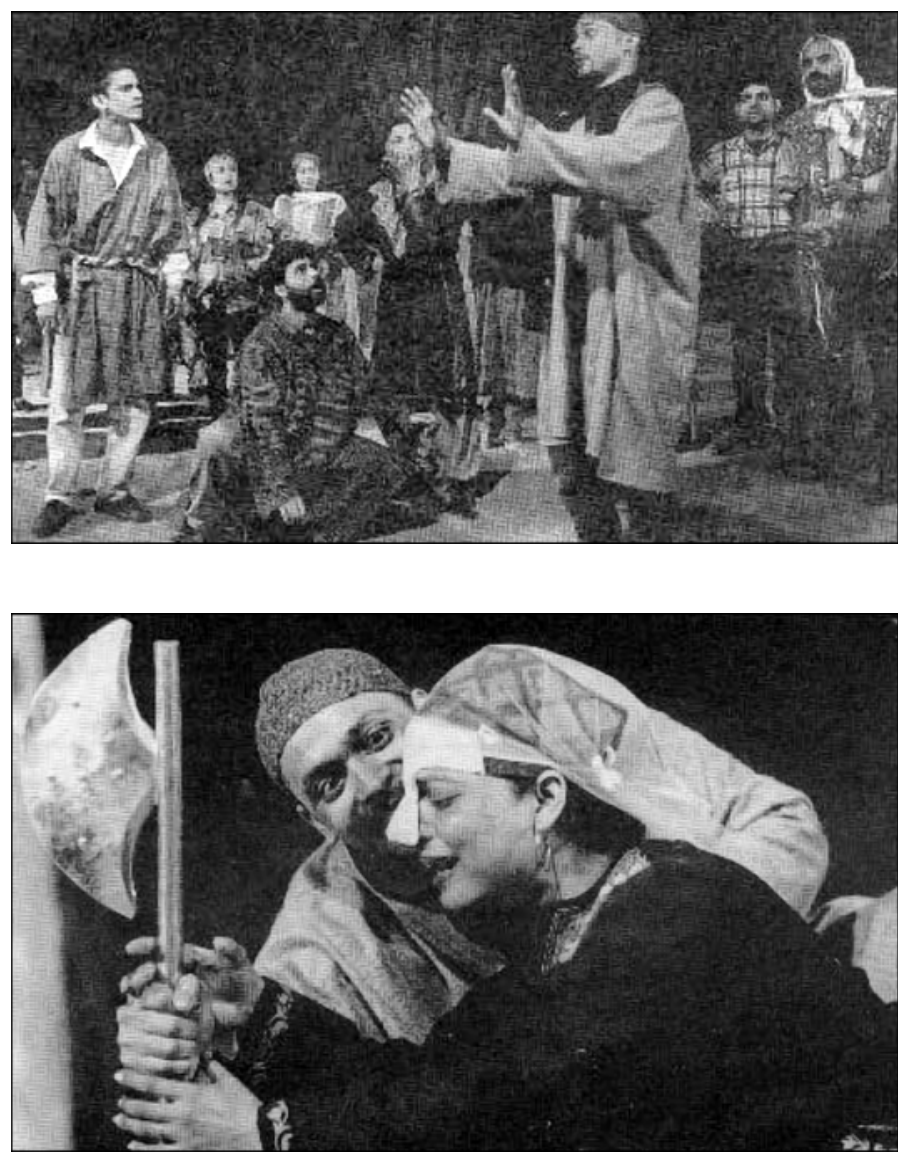
with allusions to the Bhands. Bharata's Natyashastra (2 AD) makes an oblique reference towards the mocking disposition of the folk theatre. The lacunae and loopholes of the courtly plays are identified and held up for ridicule. The Neelmatpurana (5 AD) gives evidence of the folk plays during festivals or on some special occasions. Though Rajatarangini (12th century AD) does not directly draw on these folk performances, yet there are references to plays being staged in courts and temple courtyards. Kalhana remained close to the court. Hence his oversight regarding the popular subaltern vocations is understandable. Yet one does get a hint of the temple performances - 'rangmandaps' - as occupying a kind of middle ground between the Bhand culture and the court culture. Whatever be the case, we note again the Bhand Pather coming into its own during Zain-ul-Abidin's (1420-1472 AD) benign reign. This was the highest watermark of the syncretic intercommunal cohabitation. Shrivara, a minister in the court, in his own Rajatarangini devotes a section to the celebration of the birthday of the king's son. The services of the Bhands were used to mark this event. Up to this point whichever historian writes about this art of the itinerant players, the references are sketchy and not central to their narratives. With the Mughal invasion (1586 AD) and the subsequent colonizing chapters, the visibility increases in the historical documents. The words Bhand and Pather were used in their present form during this time. Their presence is reported in the poetry of Nund Reshi or Sheikh Noor-ud-Din Wali as he is popularly called and the 'vakhs' of Lal Ded or Lalleshwari. Earlier it was mostly recognized by the name of Rang. The new vocabulary of the Sufi poetry or the theatre marks the influence of Persian. Contemporary language of these plays makes a considerable use of the medieval Sufi poetry of Nund Reshi and Lal Ded. Even the word Kashmiriyat is a derivative of the Persian. A new child character, 'bacchhakot', is shown as making its entry. Sir Walter Lawrence in his The Valley of Kashmir (1895) is very vocal about these traveling players. Seeing the suffering of the Muslim peasants laboring under the hated institution of the 'Begar', Lawrence hails this popular art as the "remover of sorrows". The mocking tradition evoking laughter since the advent of the successive invasions is unparalleled. These performances in open meadows, 'tiraths', 'isthapans', 'dargah' courtyards, under the shade of 'chinars' or during wedding ceremonies, harvest season and fairs are also termed as 'yak rang', for the predominant objective is to produce satire and evoke laughter. Tragedy is scrupulously kept away from the plot. However, underneath the seemingly innocuous comedy serious messages were transmitted through what is termed as the 'phir kath' (roughly translated as twisted talk). This feature makes it a coded narrative. The decoding act was the special privilege of the masses given their access to the local idiom. The colonizing officers, be they Mughals, 
Afghans, Sikhs or the Dogras were hard put to decode the scenes and the language used. With the officialization of this art, it has lost much of its appeal as depicted in Rushdie's novel. What used to be earlier the source of sorrow dissipating fun has lost much of its credibility and has come under the scanner.

Bhand Pather lends itself for a study of the shifting landscape of the intercommunal relationships. It is one of the unique sites on which the nuances and complexities of Kashmiriyat can be easily worked out. It has been nourished both by Hindu Shaivism and Sufi mysticism. The presence of secular characters is an eminent feature of this form. The character of Magun is a reincarnation of Bharata's 'sutradhar'. Maskhar (clown) whose number can be between 6-12, is a central character and historically the most popular and carries a dual legacy; linguistically, on the one side, the word is of Arabic origin, on the other, due to his using a hollow bamboo stick - which is the meaning of 'maskar' in Sanskrit - it bears the imprint of the classical language. The most significant feature, in my opinion, of this art rich with the antique flavor is the way it presents us a non-idealized version of Kashmiriyat. The accounts relating to the latter basically fall into two categories; either they rubbish it as being fallacious or they glorify it in heavenly terms. Bhand Pather underlines not merely the shared cultural space and the interweaving of everyday Hinduism and Islam but demonstrates practically the sharp differences as well. And yet illustrates, how, despite such differences it is not impossible to live together. In this paper, I shall attempt a complex exploration of this endangered form as a key component of tradition and its interface with modernity not merely through direct confrontation with the products like television, but also in the ideological domain.

There is everything to forgive. You can't forgive me.

If only somehow you could have been mine,

What would not have been possible in the world?

- all winter - its crushed fennel.

We can't ask them: Are you done with the world?

In the lake the alms of temples and mosques

Are locked in each other's reflections. (Ali 2002)

The lakes, in which the poet found the arms of sacred structures interlocked, have certainly grown smaller in number. And the ones existing have been reduced to such shallowness that it is doubtful if such depth can allow the creation of interlocking images in the mind. But not long back and therein lies the story - not only did the interlocking happen in the depths of numerous lakes, the wailing call of the muezzin summoning believers to prayers blended with the recitation of Granth Saheb from the Gurdwara in the neighbourhood 
areas and the pealing temple bells. The interweaving of pieties is happening now only in the fond memory of the remaining few elders. With their passage, the exhumation of the memories would not be possible. The youth, like the gravedigger in Shakespeare's Hamlet, would only recall with wonder and amusement the way lives were lived in the past.

However, the gravedigger has already emerged on the scene to reconstruct for us the days gone by. Through the presentation not merely of a few bare scattered bones but life full of flesh and blood characters. Shalimar the Clown, at one level, a sound critique of our polarised times, also offers an imaginative reconstruction of the fond, dense memories of the remnants of those cherished days. The reconstitution of what the poet saw in the lake gets refracted into different images with the same stamp of communal solidarity in the village of Pachigam. However, not many are happy with the narrative reproduction. Pankaj Mishra is one of them. Among other things, in his review of the book entitled Massacre in Arcadia for the New York Review of Books, he is posing a genuine question, a search into the answer of which leads to some challenging areas concerning the possibilities of living with so much cordiality. He wonders:

More puzzlingly, although Rushdie makes much of Kashmir's 'merging of faiths,' his muslim-dominated village has no mosque, and though Muslims revere Hindu gods, neither they nor their Hindu compatriots spare any time for Allah (Mishra 2005).

On the face of it the wonderment, occasioned by the absence of a mosque in the tradition-soaked village of the 1940s and 1950s, is not unfounded. A closer look, however, would reveal that there is not much fascinating in the discovery made by the reviewer. The absence is consciously implanted. It is nicely forged with the point Salman Rushdie is out to convey. That in the communally undivided times orthodox structures like a mosque are overshadowed by a certain innocent, unconscious celebration of a non-sectarian lifestyle. Why only a mosque, even the temple is missing from the cultural landscape, the synagogue - given that there is a Jewish family, that of Habib Joo -, too, is not present. The absences are artistically placed to reinforce and articulate the presences. The presence is that of a thriving Pachigam, where the direct interconnectedness between various denominations and an infantilizing distance from the hegemonic structures has forged a unique way of life. A way of life in which paths, with multiple intersections, are crossed with ease and the God is recognized in reverence for the other. ${ }^{1}$ At the centre of the cultural life of this Arcadian Hamlet is Bhand Pather. This folk-theatre is, at once, a point of fusion as well as diffusion. Towards its flexible form arrive multiple strands of thought and 
produce a new whole. This new whole spreads its syncretic waves across the hamlet. This arrival and return, with Bhand Pather as the rallying and reference point, governs the production of the basic harmonious spirit and a dominant wholistic ethos. Habib Joo, a Jew, ${ }^{2}$ arrives with his skills of dancing mastership, Shivshankar Sharga, a Hindu, with his music, Boonyi Kaul daughter of the vedic scholar Pandit Pyarela Kaul - with her dancing talent, Shalimar, a Muslim, with his stunning clownish acrobats. The cooperative combination of the skills emerging from the diverse sources nourishes the dominant ethos and give rise to the enamouring theatrical performances. The people living under such conditions are barely conscious of the divisive dogmas. The wholistic and inclusive anatomy of the folk art fore-grounded in Pachigam is in line with the earlier representations of the author. The widely ignored Kashmir portion of the Midnight's Children, generally speaking, breathes the same inclusive spirit. The old boatman Tai - an uncommon name but given the fact that each act of naming in Rushdie is dense with implication, this one is no exception - who symbolically connects the old with the new, the vital arterial link between various contesting strands. Though he eventually dies in the cross firing between Indian and Pakistani troops, yet he does not leave unarticulated the essential need to preserve the Arcadia. Bhand Pather, as it is illustrated in the novel, is the inner core of the Arcadia. In fact, if Pachigam is a static metaphor for Kashmir, then Bhand Pather is indubitably the dynamic, functional aspect of the metaphor. It is an organized expression of the spirit diffused across Pachigam. Precisely because of this organized aspect one is forced to ask whether the unconscious innocence I was talking about earlier can be granted to such activities. Any community, which has had a brush with structures of power, cannot perhaps be allowed to enjoy the degree of innocence pervading over this village. Be it in so-called pre-colonial societies or colonised cultures, the impulse towards an organized artistic production is almost always stimulated by a conscious thought process.

Now the question to be asked is whether such Arcadian representations, be it in the form of Tai or the Bhand Pather, had any material basis or is it merely a misinformed construction emerging from the "Other". There are actually two parallel traditions involved in the construction. On the one hand there are nineteenth-century colonial discourses with their native sympathisers, who established the story of a happy vale composed of pure unpolluted cultural practices. In this category, excluding the colonial narratives, fall such narrators as Sheikh Muhammad Abdullah ${ }^{3}$ and M.J. Akbar, to name just two. After the formation of National Conference, Abdullah continuously admired and emphasised admiration for the unique intermingling culture. In his autobiography, Aatish-e-chinar, he mentions the steps taken by him to isolate the 
divisive forces bent upon sowing the seeds of regression. His practical actions and theoretical measures to firm up the prevailing atmosphere are embodied in the Naya Kashmir plan, behind which he was the main guiding spirit. M.J. Akbar, though not driven by the same set of circumstances as Sheikh Abdullah was, yet goes on to reinstate and legitimate the classical position. A position, it is worth remembering, which has found currency in current discourses courtesy of a host of reasons, principal among which is the growing extremist strain in the subcontinent. One more sign of the same phenomenon is the recent resurgence of the partition literature. There seems to be a latent lesson deriving instinct informing the establishment of these charismatic reference points. Akbar expatiating on the virtues of Kashmiriyat goes on to say that the

message of harmony created a reservoir of humanism which became the ideological fountainhead of the modern Kashmiri mind, gave a unique quality to the Kashmiri identity, provided a conviction which long preserved Kashmir from the unspeakable and unbelievable bloodshed which Indians have inflicted upon each other in this century in the name of religion. It can only be described as the faith of Kashmir, a faith which has been witnessed by anyone who has visited the valley and had the good sense to see beyond the extraordinary beauty of the mountain, lake, forest and glade into something far greater, far more luminous, far more enchanting: the beauty of the Kashmiri heart, the Kashmiri soul (Akbar 1991).

As opposed to these espousers of the idea of mutual cohabitation approximating the ideal level, there are a number of others whose patience with this thinking is limited. In her recent publication Languages of Belonging... Chitralekha Zutshi, drawing on a variety of sources debunks the idea of such rehabitation as a constructed myth. The idea, as per her, has to do with the colonial machinations. She believes that the poetry of Nund Rishi, Lala Ded, two medieval composers of poetry glorified as the epitomes of Kashmiriyat, have a solid core of Sufi mysticism and Hindu vedantism. Closely examining pre-colonial, colonial and Dogra records, as well as the writings of the Kashmiri Pundits and Muslim spokesmen, Zutshi traces the complex process of the construction of a distinct Kashmiri Muslim identity. She argues that Sikh rule in Kashmir, under which the Muslim peasantry suffered considerable leadership, naturally led to a growing stress on the Muslim aspect of the identity of the Kashmiri Muslim majority which, in turn, functioned as a means to articulate dissent and protest. This was carried further under the Dogra regime, which increasingly relied on orthodox Brahminical Hinduism to claim sanction for itself. Her particular focus is 
on how the notion of Kashmiriyat came to be developed over time in response to wider social, cultural, economic, and political developments in Kashmir. In the process she examines how key Kashmiri leaders sought to balance their commitment to Islam, on the one hand, and to the notions of Kashmiri nation, on the other. Countenancing the point made by Zutshi is Iffat Malik. Her argument runs more or less on the same line. This author begins with a brief history of ethnic identifications in Kashmir. She points out that the

differences between Hindus and Muslims, though less acute than in the rest of India, were not completely absent. Indeed they were potentially disruptive because the state, which was ruled by a Hindu Dogra ruler, favored the Pandits and impoverished the Muslims (Rehman 2002).

However the most scathing critique believes that "if Kashmiriyat represents liberalism, Auschwitz was Disneyland" (Kaul 2003). This is the most extreme opinion nursed by some sections of the Pandit community, born of deep frustration, which, more often than never, is a direct result of their exile from home.

Keeping in mind the above it is profitable to return to Bhand Pather for the simple reason that not only does it incorporate the parallel, antagonistic views expressed, but, very importantly, demonstrates how it is not so difficult to transcend both for a peaceful co-existence. Since documentation of Bhand Pather performances has not happened, it is not known as to when the word "Bhand" made its appearance. Today, the word Bhand implies a character with a clownish touch. Even as one hears the word, humor is always lurking somewhere, and it immediately brings to mind the agrarian economy with which was intertwined the entire folk theatre. The Bhand Pather performances relied primarily on an agrarian set-up; the people who watched the performances would pay in kind in the form of rice or anything else humbly demanded by these travelling players. This exchange would happen either immediately or the return would be made during the harvest season when the group of travelling players would send a person known to them for the collection of rice, which was later divided, as per their own conventions, among the players. The performances are not made on elaborately designed stages but in fields, open meadows, terraced maize fields, shrine courtyards and on the sides of the roads. These open settings give a lot of freedom to the action in play. For example, during the performance in an open field with a tree or two around, the clown may climb the tree and execute a few antics providing a lot of fun. Making use of the natural objects is thus an integral component of a performance. This has also to do with their itinerant character; frequent movement from one place to the other does not 
allow the artists to produce sophisticated and permanent settings. Except for the barter element, the performers are more or less self-reliant. They would carry the costumes to be used in trunks along with them. To augment their self-reliance, some of the Bhands arranged a side trade too. In some areas where the raw material was easily available, they would make Kangris, the fire pots used to keep the body warm during winter. So whenever before the winter season they would travel, they would carry these garishly designed Kangris and sell at the place they staged the performance. The performances are normally held before and after the afternoon prayers. Sometimes when the play went on into the evening, traditional lighting system was used like a lantern or setting alight some pieces of combustible wood tied to the end of a stick and subsequently the gas lamp came into vogue. Usually, given the heterogeneous nature of the audience including children, women and the elderly, the plays are brought to a close before dusk sets in so that everybody reaches home in a safe manner. With the advent of militancy, not only were the wedding ceremonies, which earlier were a nightlong affair, restricted to daytime but also all manual functions had to strictly be finished off before sunset. For night belonged to multiple sources of terror.

The narratives have been passed down from generation to generation. There were no written plays. However, there used to be a basic draft. This draft was modified from time to time to enact a new play. The plays are of types: there can be Watl (Cobbler) Pather, Pahil (Shepherd) Pather, Waza (Cook) Pather, Munshi Pather, Goswani (Hindu priest or a 'sadhu') Pather, Chana (Carpenter) Pather, Mughal Pather and so on. With the presence of 6-12 clowns, these characters are satirized, in the process evoking laughter. Historically, as would be mentioned later, the Bhand Pather plays had a therapeutic character in that laughter and amusement is the basic sum and substance. The tragedies and serious subjects are scrupulously avoided. The characters are, as the titles indicate, secular in orientation. The vocations and professions are satirized and not a particular person or community. An important linguistic component of some of the plays is the phir kath. The phir kath makes them coded narratives in which meanings and messages are constituted in a manner so as to make only the local people able to understand them. This was done to avoid the trouble from the officers of the different ruling regimes. In their presence, recourse was taken to subtler methods. Over a period of time phir kath became an inalienable part of the popular experience Even today such a mode of communication is found among the carpenters, goldsmiths, and cobblers. The fact, however, remains that phir kath is/was a symptom of slavery. The necessity of this mode was felt under the consciousness of the colonial subjugation. It is interesting to learn about the survival tactics, however, it is not hard to imagine the repercussions which ensued upon exposure by the colonial officers. 
The prayers are central to performances. They begin with invocations and are concluded with a blessing prayer wishing everyone happiness and prosperity. This is particularly so if the play is shown in the shrine courtyards. Then along with the conventional players, intercession of the saint whose grave is nearby is sought and a part of the collection from the audience is donated to the caretakers for the maintenance of the shrine. Since shrines of numerous 'pirs' and saints dot the landscape and are frequently visited by the saint worshipping population, a performance close to them attracts a wider audience. With the orthodox interpretation of Islam gaining ground, not only have the attempts been made to replace shrines as central cultural sites but the artistic production thriving under their shade has also suffered.

It is not a vain claim that Bhand Pather is perhaps the oldest known art form in the sub-continent. Though coming a little later than Bharata's Natyashastra, the Neelmatpurana gives details of the festivals of original inhabitants after the valley - then known as Sati Sar - was drained of water. Different occasions were chosen for different festivals. On these specific days some plays of rudimentary plays, along with the general celebrations were also staged. Natyasastra is an elaborate manual on dramaturgy. It marks a certain stylization of the crude, folk performances. Innumerable details are laid down for the construction of the stage, the enactment of plays, role of characters and so on. For the first time sacralization became an important constituent though an elaborate set of rituals. Interestingly, Bharata mentions a dance called 'Bhandka', which, Ahinavbharati, as per Prof. Pushp, calls Bhandanachun (the dance of the Bhanda). Abhinabharati, however, records that even as stylization process of the primeval folk plays was underway from scholars, the folk theatre, removed from the portals of stylization, also simultaneously existed. In this parallel theatre, carrying forward its own tradition, the high theatre was made the target of mockery. The lacunae and the loopholes were identified and converted into a potential source of fun. The precise nature of this rather obscure theatre is not known. It is only in Kalhan's Rajatarangini, recording the history from the war of Mahabharata up till $1149 \mathrm{AD}$, that we get to know about the interface between folk theatre with its own paraphernalia and the high theatre close to the court. Kalhan was the son of Champak, a minister in King Harsha's court. Therefore his familiarity with court etiquette and the theatrical developments is undoubted. The Rangmandap during his times became the principal link between the folk and the court theatre. The Rangmandap was the temple compound. With the coming of Islam, new developments occurred. With gradual changes in different cultural facets, it also gave a new vocabulary for older modes of cultural expression. The word "natya" was replaced by Pather. For 
the first time words like Pather, Magun and Jashn find a mention in Nund Reshi's (1377-1442) poetry. Similarly, the Persian word adakar, for actor, also makes its appearance around the same time. Like Magun - a corruption Mahagun, one with multiple, high qualities - Bhand is also, probably, a continuation of some earlier form. Whatever be the case, it is widely believed that the Sufi mystic in his childhood days, watched these performances. It is therefore no surprise that there are references to Bhand Pather in his poetry as there are in Lalleshwari's (1320-1390). Even Mehmood Gami and Ahmed Batwari, two medieval poets steeped in Sufi mysticism, mention the prevalence of Bhand Pather. How could it be otherwise? The popularity of the Bhands could be gauged from the invitation, as per Srivara in his Rajatarangini, given to them for a special performance on the occasion of the birthday of King Zain-ul-Abidin's son.

Drama in Kashmir had touched a high pitch in Sultan Zain-ul-Abideen's time (1420-1470) when Bhodah Bhatta wrote his Zaina Villasa, and when the stage plays enjoyed royal patronage. The contemporary historian, Srivara, reports in his Zaina tarangini that an actress singer could depict 49 emotions in her dancing as harmoniously as the musical cadences demanded. [---] Drama [---] continued flourishing till the fall of Chak dynasty in 1586 AD. Sultan Hassan Shah surpassed all his predecessors in synthesising the local fine arts with those of the Iranian and Indian prototypes. (Hajini 1985)

Either during the Mughal rule or the Afghan period, a very special character appeared on the theatrical scene. It was called Bacchhakot. Bacchhakot, basically a young male, through cross-dressing would amuse the audience by playing the role of a female character. Not only does a Bacchhakot demonstrate his talents during the Bhand Pather performance but he has also found his ground outside the realm of dramaturgy. Not very long back it was a common sight in rural areas to find a Bacchhakot regaling the audience during the weddings. He would mingle with the women singers, dance with them and thus keep the night of festivity rolling on. On these occasions the show would either only be managed by a single Bacchhakot or two to three of them. The fee is already fixed and besides the payment, they partake of the food and other delicacies as part of the acknowledgement of their services rendered. The quality of a Bacchhakot's voice was of immense significance. The voice used to be naturally inclined towards the feminine side. Therefore, one of the endowments, they possessed, was their naturally feminine voice. In a way, from this, one could infer that social misfits making use of their congenital shortcomings had carved 
a respectable niche for themselves or the society, taking recourse to adjustment mechanisms, had opened a space of rehabilitation for them. Any which way we look at it, Bacchhakot came to prominence with the passage of time and firmly planted himself as an inalienable part of the cultural imagination.

The Sikh rule (1819-1846) and the Dogra rule (1846-1947) are widely recognized as the worst periods in terms of the general well-being of the population. In describing the conditions under the Sikhs, William Moorecraft, the first English traveller to visit the valley, wrote, "everywhere the people are in the most abject conditions, exorbitantly taxed by the Sikh government and subject to every kind of extortions and oppression by its officers" (Moorecraft 1841: 123-124). The worst was yet to arrive. It was the Kashmiri "Muslim peasantry that found itself shouldering the heaviest burdens of the state governments unfair policies" (Lawrence 1967: 126-27). With little to wear and a bare foot, "a Muslim peasant presented the appearance rather of a starving beggar than of one who filled the coffers of the state" (Bazaz 1954: 144). "The Muslim peasant," writes Narinder Singh, "laboured in the fields during the six warmest months of the year to pay taxes to the state, rental to the proprietor, interest to the money lender, and graft to the local officials" (Singh 1992: 31). Many who went outside the valley in search of work "died at unknown places, uncared and unwept" (Bazaz 1954: 144). The domineering system continued for such duration and to such depth that an internalization of servile practices materialised. The self-esteem got gradually eroded. "The Kashmiri hug slavery to his bosom and was a stranger to the dignity of the self, ashamed of his ego" (Birdwood 1956: 20). The hated institution of Begar $^{4}$ ruled the roost. The peasants were taken away from their homes to serve in remote and inhospitable conditions. An Englishman, who travelled to Kashmir in the mid-19th century, described the structure of misery inflicted by it as follows:

When a man is seized for this form of begar his wife and children hang upon him, weeping, taking it almost for granted that they will never see him anymore. A gang of these poor creatures, heavily laden with grain, toiling along the desert crags between Astore and Gilgit, on a burning summer's day, urged on by a sepoy squad, is perhaps as pitiable a spectacle as any to be seen on the roads to Siberia. But these were not convicts or criminals, they were Mussulman farmers, harmless subjects of the Maharajah (Knight 1983: 67).

It is in this historical backdrop that the growth and popularity of the Bhand Pather has to be placed. With the limited resources available to them, the folk artists gave expression to the privation and sufferings of the peasants. Given 
their distance from the centres of power, they could vent their anger against the oppressive rulers through satire. The distant political masters were not the only targets of satire but it was also creatively directed at their local collaborators, a munshi, for example, or a Daroga. Rich with rustic humour produced as much from satire as from the costumes, body movements and the distinct linguistic turns and twists, it is not for nothing that Walter Lawrence, the Land Settlement Officer, in his book described these travelling players as "remover of sorrows." Thus the pre-existing cultural artefacts were refashioned and employed to absorb the miseries and sorrows. At another place he writes that almost "everything save air and water was taxed" (Lawrence 1967). Supporting this observation is another Englishman. He notes that "the butchers, bakers, carpenters, boatmen and even prostitutes were taxed" (Younghusband 1954: 129-130). The natural calamities spared not even the removers of sorrows. Lawrence during the course of his travels witnessed the death of an entire village of Bhands in Soibugh in the present day Budgam district. It was in the year 1877 and the cause of the death was plague.

The twentieth century came with a new baggage of problems, posing new challenges before the artists. Symbols of modernity like roads, telegraph and later television made inroads into the guarded cultural terrain. Even in Salman Rushdie's novel we find as to how the introduction of television in the village of Shirmal divides the audience. The programmes screened were ideologically loaded which forced the pandits to leave the tent in which Hasina had put the television for the people to watch. Therefore it is clear that the ingress of the symbols of modernity into the cultural realm was not purely innocuous. Though discernible in these products of modernity, yet the most significant influence came with the crystallization of the contending visions of nationhood and in the current analysis let us take Bhand Pather. The latter worked in ways peculiar to the local population uninitiated into the manipulations of the outside world. With the dissemination and the deeper penetration of these ideas, traditional loyalties came under attack, new claims with their dramatic appeal surfaced on the scene. Mahatma Gandhi's opinion that "Hindustaniyat should be based on Kashmiriyat" (Ghandhi online source) is emblematic of such a condition. It exemplifies the manner in which folk culture, after all Bhand Pather is a representative element of such folk culture, is used to imagine the nation, restructure the past and think through the folk structure with nationalistic thinking. Now, at this stage, two things have to be kept in mind: one is, as was observed in the foregoing, that cultural signifiers like Bhand Pather were mostly constitutive of a distinct self-identification. The entire history of this form over the past many centuries suggests the creation of a dominant 
other and the dominated self. Therefore positing such a self as the template or a reference point for the construction of the other is a contradiction in terms. Though it is true that the other presently is not the one which earlier determined the aesthetic content of folk theatre, yet it is equally true that the self has not reconciled to the representation of the current other as a consensual partner but perceives it as more dispensation in continuation of the preceding. Hence, folk theatre, far from capable of imagining the grand nation, is actually allowing itself to be used for the imagination of a smaller, more or less homogenous entity. ${ }^{5}$

Second issue is precisely the imposition of the burden of Edenic cohabitation, which unsurprisingly divided the recipients along sectarian and religious lines, for it raked the incendiary memories by subtly making a strong claim on the loyalties of the inhabitants. The consequent outcome was the shaping up of narrow identities. As it happens in the aforementioned novel, many Muslim youth in the village refashion themselves and of all the people Pandit Gopinath Razdan enacts the role of a spy. No wonder, he is waylaid, caught and killed spurring the creation of new fault lines of animosity. One is not arguing whether nationalist thinking - a product of modernity - and its subsequent ramifications in the form of the breakdown of conventional certainties, was inevitable, but the point is that it led to an appropriationist hunger, which, in turn, disrupted such local cohesive forms as the Bhand Pather. The appropriationist logic worked in many ways; the Radio Kashmir was founded on July 1, 1948, ${ }^{6}$ exactly when the sub-continental ideological and geographical frontiers had been freshly redrawn. The plays broadcast telescoped these emergent identities. They were collected and reproduced with significant editing and sanitization of the original. The sanitization signified an aggressive appropriation drive to strengthen the larger idea at the expense of the smaller frames. The history of Bhand Pather, at least at the height of its popularity, underscored, through an overarching mocking tradition, triumph of the small and the weak over the big and the powerful.

Now coming back to the Bhand Pather and its waning fate, a very significant implication of the nationalistic intervention into the realm of the various forms of folklore, was the convenient rejection of a very complex local history. The Bhand Pather as a typical cultural specimen is an ensemble of differences and commonalities between the two communities, and yet, one does not fail to appreciate an underlying cohesive vision, born as much of the psychological makeup of the populace, economic compulsions, historical fusion without excluding the geographical causes. Even today, rare though they are, when a performance is underway one is struck by the importation of rituals and cos- 
tumes from Hinduism. The characters like Magun and Masker owe their origin to ancient Sanskrit texts. The invocation in the beginning echoes Bharata's insistence in Natyasastra to invoke the creator for having blessed them with the Natya. The sacralization of the theatre has, since then, been an integral part of its growth and development. In ways which surprises the foreigners, Bhand Pather became the point of convergence of different yet mutually inflected traditions, creating, in the process, a unique difference-bridging crossfertilisation. That popular culture can nurture intercommunal linkages is eminently exemplified by Bhand Pather.

The differences, however, are as much in number as are the similarities. Most of the performers are Muslims excepting the ones in the Bhagat Theatre of Akingam. The Brahmins who took up this vocation were gradually looked down upon. The story goes that Devi gave Darshan to the eldest in the village of Akingam. She gave him a sarangi and asked him to sing. She told him that he should go to the Deodhar forest of Akingam and sing there for her. Initially he refused for he believed it was against his caste. He ran away to the Lidder area. But as luck would have it, he became blind. The Devi chasing her own interests came in the dream of an Officer of the Lidder area and asked him to send the man back to his village. He was sent. Light came back to his eyes and since then decided to sing. The singing tradition continued ever since. The belief is that if singing is stopped, Devi would be offended. The incident highlights the reluctance to associate themselves with the artistic engagements of the other community. This reluctance could also be located in the given political condition. The widespread patronage extended to the Pandit community naturally created a stake for them in the continuation of the regime. The fallout was the antagonism engendered between the two communities, an antagonism requiring only a spark to snowball into a major confrontation. The sparks were not hard to come by, they flew thick and fast till the two communities lost track of each other and the poet wondered:

If only somehow you could have been mine

What would not have been possible in the world!

The traveller Bernier has reported the impassability of non-Jews into the landlocked valley. The impassability was an enforced measure. The psychology behind this administrative measure is not very hard to fathom. Surrounded by mountains, the mental habits evolve in manner peculiar to the habitation. A sense of natural security and a keen apprehension of the same being threatened by unknown dangers are parts of this psychological make-up. Therefore the alien consciousness is too acute to be understood by those dwelling in the 
natural plains devoid of the awesome presence of the mountains. This consciousness is the seed bed of the ubiquitous suspicion of the Other and at the same time an uncommon uniting thread among the dwellers of these mountain ringed or ocean ringed locations. My intention is to draw attention to this rather apolitical dimension of the source of the mutually cordial cohabitation. No doubt the role of the topography in forging cross-community linkages has been marginalized. However its importance is thrown into sharp relief once it is binding - force energy is posited against the Metro politico-economy's sanitized appropriation of the aeons-old cultural specimens. Then for replication purposes in places where the context is more or less conducive to such processes - and for the consolidation of the larger desires rooted in Modernity - a rewriting of what is otherwise a multi-helical history is undertaken. Such conscious reinventing processes informed, in part, by the insidious motive of throwing behind the frontiers of politico-ideological frontiers, in the long run, through myriad agencies of reinvention, end up preparing the epitaph small syncretic traditions. Even as auditoriums and permanent ideologically charged stages are constructed, Abdullah Noman's hands freeze into claw-shaped objects rendering him incapable of participating in the group plays. The artistic death of his hands inscribed another foreboding - the days of Bhand Pather are over, an age of fury has dawned.

\section{Comments}

${ }^{1}$ In this regard it is interesting to remember what Patrick Colm has to say about the absence of Gandhi from the Midnight's Children. The argument goes that in exhausting all options through the final cracking of Saleem Sinai - who read in his personal history a metaphor for postindependence India - a centre staging of Gandhi occurs. The same interpretation rigidly used would certainly not apply here. A modified version would. What is centre staged here is also a mosque but one which allows all access, in which ancestral voices are the guiding principles. In this mosque there is no unitary authority but multiplicity. This mosque is the ethereal pachigam itself.

2 The view that Jesus survived crucifixion, married, had children, lived to be 120 , and is buried in Kashmir is mostly propagated by the Ahmadiya Muslims, a rationalist Islamic sect established in the late 19th century in India by Mirza Ghulam Ahmad Qadiani. He writes:

After surviving the crucifixion, Jesus Christ arrived in Kashmir, where he took residence for the remainder of life. There he ministered to the Israelite tribes of the area, continuing to preach. He eventually married a woman named Maryan, who bore him children, and so the theory states, he died at the age of 120 years. His tomb is located in the mohalla Khanyar district of the capital city of Srinagar, Jammu and Kashmir, Northern India, and is called the Roza Bal (the site of the honoured tomb) (Ahmad, 
Ghulam. As quoted by Dr. Rashid in "Where is the Grave of Jesus?"

28.04.2006. http://www.tombofjesus.com/welcomeall.htm)

The first book to gain widespread attention for the view that Jesus spent time in India (and Persia and Tibet) during his early life was Nicolas Notovitch's 1894 work The Unknown Life of Jesus Christ. Later Holger Kersten took up this in Jesus Lived in India.

As far as the Israeli tribe theory is concerned, there are still some rituals followed in the valley, which closely resemble with the orthodox Jews. For example, the wearing of the skullcap, which is not an uncommon site in the rural areas. Second, the postchildbirth 40-day purification rite is practised widely and third, the burial rituals including the position of the corpse inside the grave is reminiscent of the Jewish burial rites.

3 The sarpanch in the village is named, not without significance, Abdullah Sher Noman. It was believed that for the state there was Sheikh Muhammad Abdullah and for the village, Abdullah Sher Noman. While the former was hailed as the Lion of Kashmir, the latter was the sher of Pachigam Both of them were eulogised as bulwarks against communally divisive agendas. It is not for nothing that the smaller Sher, before his transition into a Noman, endorses the marriage of his son with a Hindu dancer, Bonyi Kaul.

${ }^{4}$ A scene that would never go off my mind was the one I saw while returning from the Boarding School, on vacation, back to my home, a few miles down the road. Someone had died. So it was a day of Hartal and three or four friends with me had to walk all the way till we reached home. Since it was also the Amarnath Yatra season, a few buses packed with the pilgrims came up. On the side of the road was walking, halfbent, an old farmer with a sack of rice on his back. As the buses came closer, a soldier standing close-by on guard for the Holy Amarnath cave pilgrims kicked this old man. The rice fell all over the place and the man went rolling down into the stream. Nothing more than this happened. Just the passengers with heads out of their windows and the brave dark-faced soldier exchanged a warm, triumphant smile. We saw what happened but merely passed dominant other by as the farmer struggled to get out of the stream, staring at the scattered rice grains. Some metres down the road a friend broke the silence "Dogra Raj couldn't have been worse than this."

5 Stuart Blackburn in his book Print, Folklore, and Nationalism in Colonial South India argues that there is a vital link between the imagining of nation and the folklore. He points out that in relatively homogeneous states of Germany, Finland and Scotland, folklore, in its various manifestations, was seen as the repository, which had a crucial role to play in shaping the nationalist identities. He writes, "the German states were the primary source of ideas that led to movements in which folklore was put to the service of European Nationalism. In the late eighteenth century, the poet Johann Gottfried von Herder developed his theory of the folk and especially folk poetry, which he claimed was a repository of national memory and expression of the national soul" (Blackburn, Stuart. Print, Folklore, and Nationalism in Colonial South India. Delhi: Permanent Black, 2003. p. 149). In heterogeneous societies as India, a reinvention of the nation on the basis of folklore is bound to come a cropper for the simple reason of the profound heterogeneity characterizing folklore. Individual units, having remained under layers of subordinations, used their local idiom embedded in folklore to recast their self. Hence, the Indian nationhood is, in a way, based on the appropriation of multiple self-fashioning enterprises. 
6 Every year a fair used to be held a little above the foot of a hill, near the temple of Shiva Devi, in the village of Akingam. In this fair a lot of logistic support was provided by the Muslims of the neighbouring villages. This happened till 1947. After that as the general condition around deteriorated, and as their economic position weakened due to the loss of audience to other sources of entertainment, this annual tradition developed cracks. It is worth mentioning that these 'pandit Bhands' or 'Bhatta Bhands', as they are locally called, were playing the musical instruments like 'sarangi' and 'sitar', long associated with the Sufiana Kalam in Kashmir, with considerable expertise.

\section{References}

Ali, Agha Shahid 2002. Selected Poems. Srinagar: Agha Shahid Ali Foundation.

Akbar, M.J. 1991. Chapter 1. Kashmir: Behind the Vale. New Delhi; New York: Viking, 27.04.2006 http://www.mjakbar.org

Bazaz, P.N. 1954. Struggle for Freedom in Kashmir. New Delhi: Kashmir Publishing Co.

Birdwood, Lord 1956. Two Nations and Kashmir. London: R. Hale.

Ghandhi, Mahatma. As quoted by Vidhu Vinod Chopra in an interview with Kanchana Suggu. 26.04.2006. http://www.rediff.com/movies/2000/oct/24vidhu.htm

Hajini, Prof. Mohiudin. 1985. An Outline of the Growth of Various Forms in Kashmiri Literature. In: The Literary Heritage of Kashmir. Ed. K.L. Kalla. Delhi: Mittal Publications, 25.04.2006. http://vitasta.org/2001/2.4.html

Kaul, S.K. 2003. Kashmiriyat - the face behind the veil. SK Media. 29.04.2006. http://www.huk.org/articles/0403/198.html

Knight, E.F. 1983. Where Three Empires Meet. London: Longmans, Green and Company.

Lawrence, Walter 1967. The Valley of Kashmir(1895). Srinagar: Kesar.

Mishra, Pankaj 2005. Massacre in Arcadia. Rev. of Shalimar the Clown, by Salman Rushdie. New York Review of Books 52.15. 29.04.2006 http://www.donkeys-party.com/ articles/mishra_on_rushdie.html

Moorecraft, William. 1841. Travels in the Himalayan Province of Hindustan and the Punjab etc. London: John Murray.

Rehman. 2002. Rev. of Kashmir: Ethnic Conflict, International Dispute. By Iffat Malik. Karachi: Oxford University Press. 26.04.2006 http://tariqrehman.com/bookie/ iffat\%20Malik.htm

Rushdie, Salman 2005. Shalimar the Clown. New York: Random House.

Sikand, Yoginder 2003. Kashmiriyat and Islam. Rev. of Languages of Belonging: Islam, Regional Identity and the Making of Kashmir, by Chitralekha Zutshi. Delhi: Permanent Black. 28.04.2006. http://www.himalmas.com/2004/may/review_2.htm

Singh, Narinder 1992. Political Awakening in Kashmir. Delhi; Chandigarh: H.K.Publications.

Younghusband, Sir Francis 1954. Kashmir. As quoted by P.N.Bazaz The History of Struggle for Freedom in Kashmir: Cultural and Political. New Delhi: Kashmir Publishing Company. 